\title{
ROLE OF AL-QUR'AN READ AND WRITE ABILITY TOWARD ACHIEVEMENT OF ISLAMIC EDUCATION FOR STUDENTS AT SDN INPRES 12/79 KAMPUNO ATTOBAJA VILLAGE BAREBBO SUB-DISTRICT BONE REGENCY
}

\author{
Muh. Harta \\ Department of Islamic Education \\ IAI As'adiyah Sengkang \\ Jl. Veteran No. 46 Sengkang, Kab. Wajo, Sulawesi Selatan, Indonesia. 90911 \\ E-mail: muhammadharta1956@gmail.com
}

\begin{abstract}
This study examines the ability to read and write Al Qur'an and its effect on learning achievement of Islamic education for students at SDN Inpres 12/79 Kampuno, Barebbo Sub-district, Bone Regency with main issues (1) What is the level of reading and writing ability of the Qur'an for students in SDN Inpres 12/79 Kampuno, Barebbo Sub-district, Bone Regency? (2) What factors influence the ability to read and write the Qur'an for students at SDN Inpres 12/79 Kampuno, Barebbo Sub-district, Bone Regency? (3) the effect of reading and writing al-Qur'an on the learning achievement of Islamic education at SDN Inpres 12/79 Kampuno, Barebbo Sub-district, Bone Regency?. To answer these problems, the authors use library research, that is, researchers examine theories in books relating to reading and writing of the Qur'an and field research, researchers examining data taken in the field, which consists of questionnaires, interviews (interviews), observations, documentation and data analysis methods inductively, deductively and comparatively. Results showed that the ability to read and write Al Qur'an for students in SDN Inpres 12/79 Kampuno, Barebbo Subdistrict, Bone Regency was fluent. Factors that influence the learning achievement of Islamic education for students in SDN Inpres 12/79 Kampuno, Barebbo Sub-district, Bone Regency are internal and extrenal factors. The ability to read and write the Qur'an has a significant influence on the learning achievement of Islamic education for students in SDN Inpres 12/79 Kampuno, Barebbo Sub-district, Bone Regency.
\end{abstract}

Keywords: Islamic education, learning achievement, read and write Al-Qur'an

\begin{abstract}
Abstrak: Penelitian ini mengkaji kemampuan membaca dan menulis Alquran dan pengaruhnya terhadap prestasi belajar pendidikan agama Islam pada siswa SDN Inpres 12/79 Kampuno Kecamatan Barebbo Kabupaten Bone dengan pokok bahasan (1) Berapa tingkat Kemampuan membaca dan menulis Alquran siswa di SDN Inpres 12/79 Kampuno, Kecamatan Barebbo, Kabupaten Bone? (2) Faktor apa saja yang mempengaruhi kemampuan membaca dan menulis Alquran pada siswa SDN Inpres 12/79 Kampuno Kecamatan Barebbo Kabupaten Bone? (3) Pengaruh Membaca dan Menulis Al-Qur'an terhadap Prestasi Belajar Pendidikan Agama Islam di SDN Inpres 12/79 Kampuno Kecamatan Barebbo Kabupaten Bone ?. Untuk menjawab permasalahan tersebut penulis menggunakan studi pustaka yaitu peneliti meneliti teori-teori dalam buku-buku yang berkaitan dengan membaca dan menulis Alquran dan penelitian lapangan, peneliti meneliti data yang diambil di lapangan yang terdiri dari angket, wawancara (interview), observasi, dokumentasi dan metode analisis data secara induktif, deduktif dan komparatif. Hasil penelitian menunjukkan bahwa kemampuan membaca dan menulis Alquran siswa SDN Inpres 12/79 Kampuno Kecamatan Barebbo Kabupaten Bone lancar. Faktor yang mempengaruhi prestasi belajar pendidikan agama Islam pada siswa di SDN Inpres 12/79 Kampuno Kecamatan Barebbo Kabupaten Bone adalah faktor internal dan faktor ekstrenal. Kemampuan membaca dan menulis Alquran berpengaruh signifikan terhadap prestasi belajar pendidikan agama Islam pada siswa di SDN Inpres 12/79 Kampuno Kecamatan Barebbo Kabupaten Bone.
\end{abstract}

Kata Kunci: baca tulis Al-Qur'an, pendidikan Islam, prestasi belajar

\section{Introduction}

Allah and His Messenger commanded to read and understand the Qur'an so that the reader knows the principles of guidance contained therein and can guide his life in all aspects in accordance with the principles in it. The purpose of all that is the salvation of the world and the hereafter, therefore the purpose of reading the Qur'an is in accordance with the sole purpose of salvation from Allah SW'T.

The Prophet Muhammad SAW said:

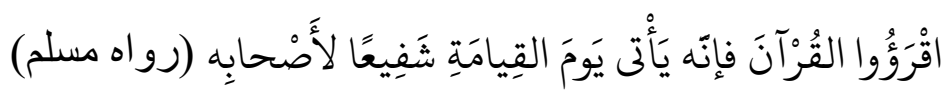


Meaning:

"Read the Qur'an because actually it will come to be an Syafa'at/defender on the Day of Judgment for those who always read it".

There are other objectives of the reading of the Qur'an, although comparatively less important, they are practically inseparable from the lives of the Muslims. One of these goals is to get blessings (barakah) from saying the sentences of God (the word of Allah SWT) with respect in an appropriate event. This aim is evident from what Muslims have done at the beginning of marriage kbutbah, meetings of ulama and at other similar events.

Al-Qur'an al-Karim is a book of God which has miraculous power, there will not appear sleaze both both from the front and from behind, passed down from substances that are all wise and most praiseworthy. Various verses and surahs contain all religious and world affairs, combining the happiness of the world and the hereafter, revealed as guidance and light for all humans. Al Qur'an eliminates false beliefs, false tales, false worship, deviant religion, turning darkness into bright light, replacing misery into happiness, turning despair, delusion and error into guidance and organized civilization, displacing and replacing ignorance with science, the beauty of art, literature, and civilization then grows from the depths of his soul all expectations in his favor, will to safety and light. The Qur'an altered the human community from the dark black that was raging, worshiping the taghout, flowing the blood of people without feeling guilty, seizing property and honor; become a community of life that is full of pleasure, security, calm, peaceful, peaceful, independent, fair, a sense of brotherhood, prosperity and civilization that leads to the happiness of individuals, communities, nations and all people (Raihan, 2005).

SDN Inpres 12/79 Kampuno is one of the formal educational institutions under the Ministry of Education and Culture that provides teaching and education at the primary level in Attobaja Village, Barebbo Sub-district, Bone Regency, besides studying religious education in schools it also provides special guidance on read and write the Koran to students outside school hours three times a week.

Al Qur'an comes from the word qaraa which means reading or something that is read. In terminology the Qur'an is kalamullah which was revealed to the last prophet Muhammad, through the intermediary of the Angel Jibril. Al Qur'an is written in the Mushaf and reach humans in mutawattir. Reading the Qur'an is worth worshiping, beginning with surah al Fatihah and closing with surah an Nas (Suryana, 1997). As the main source of Islamic teachings, the existence of the Qur'an is needed by humans. Al Qur'an contains life instructions about various things. Al Qur'an also functions as a judge or referee who manages the course of human life so that it runs straight so that when Muslims disputed in all their affairs, they should be entitled to the Qur'an (Nata, 2000). As the last holy book, al-Qur'an is not revealed only for a certain people or for a certain time, but for all mankind and applies for all time so that the teachings cover the extent of the problems faced by all humanity. The Qur'an is the most powerful spiritual force because only with al-Qur'an can humans progress toward perfection. Al-Qur'an not only to read with melodious songs, not only for musabaqah, but must be functioned (socialized) into the community.

The Qur'an is the "spirit" that gives intrinsic life to those who are guided by it, syifa (medicine) all kinds of spiritual diseases suffered by humans, nur which gives light guidance for those in the darkness, al-buda (Instructions) to the straight path, rahmah (favor) for those who are struggling to find happiness. Learning and teaching the Qur'an is a noble and sacred obligation. In the hadith of the Prophet Muhammad which was narrated by Imam Bukhari stated that:
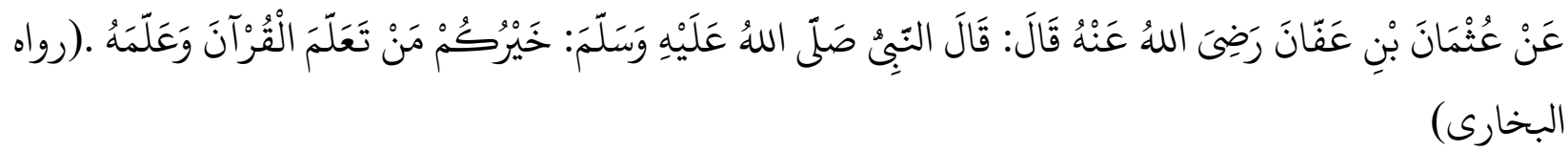

Meaning:

From Utsman RA. Rasulullah SAW said: "The best of you are those who study the Qur'an and teach it".

Reading the Qur'an is not the same as reading a textbook or storybook but it requires special knowledge to be able to read it properly and correctly. The science in question is the science of qira' atil 
Qur'an. Every Muslim must learn to read the Qur'an because the intelligence of reading the Qur'an is a daily necessity for the life of a Muslim in the practice of religious teachings. Therefore, it is necessary to develop a method of teaching the Qur'an. This is needed by the Islamic community who want to be able to read the Qur'an well in a short time.

Daradjat et al (1995) revealed the contents of the lessons of the Qur'an, which include:

a. Introduction of hijaiyah letters, namely Arabic letters from alif to $y$ a.

b. How to sound each bijaiyah letter and the properties of the letter; this is discussed in the science of makbraj.

c. The form and function of punctuation, such as syakal, syaddah, maad, tanwin and so on.

d. The form and function of stop reading signs (waqaf) such as absolute waqaf mutlak, waqaf jawaz, and so on.

e. How to read, sing with a variety of qiraat contained in qiraat science and naqham science.

f. Adabut tilawah that contain the procedures and ethics of reading the Qur'an in accordance with the reading function as worship.

Teaching the Qur'an at the initial level contains an introduction to bijaijab letters and sentences (words) then an introduction to punctuation. Practicing and getting used to pronounce Arabic letters with true makhraj at the first level will make it easier to teach tajwid and songs at the next level, which is reading with rhythm.

Factors that influence student-learning achievement are actually very many types, but the author can classify into two factors, namely: internal factors that come from students and external factors that come from outside themselves or the environment of students.

a. Internal factors is a factor that influences students' learning achievement sourced from students which includes physical factors, the level of intelligence or intelligence of students, students' attitudes, students' talents, students' interests and students' motivation.

b. External factors is a factor influencing students' learning achievement arising from outside themselves learners which include family environment, school environment and community environment.

Learning achievement achieved by someone or in these case students is the result of a combination of several kinds of factors that influence each other.

\section{Materials and Methods}

This type of research is a qualitative study that aims to understand the phenomena experienced by research subjects by means of descriptions in the form of natural words and language and by utilizing various natural methods (Sukidin \& Basrowi, 2002). The research approach used is educational and psychological approaches. Educational approach is intended to explore aspects of the problem between the role of the teacher of moral subjects and the character of students in SDN Inpres 12/79 Kampuno. While the psychological approach is to get knowledge related to the mental condition of teachers and students relating to the behavior, knowledge, feelings, and thoughts about the object being studied.

Data collection methods used in research are as follows:

a. Library research

Data collection is done in the form of reading a book that has to do with the problem being discussed.

In this library research, conducted in two ways, namely:

1. Direct quotation, by quoting the text of the book without changing its editor.

2. Indirect quote, by quoting the text of a book by changing its editor without changing its meaning.

b. Field research is the data collected conducted in the form of research in the field using the following techniques:

1. Observation, is a method and technique of data collection by systematic observation and recording of symptoms or phenomena that exist on the object of research. In this case, the authors made direct observations of the headmaster, teachers and students of SDN Inpres 12/79 Kampuno.

2. Interview, is a method for obtaining data from respondents by conducting direct interviews with headmaster, religion teacher and other teachers or students regarding research variables. 
3. Documentation, is a method of selective data collection using documents or research results that have been made available at the research location or related institutions, relating to the objects and problems studied (Hadi, 1994).

In processing and analyzing data, the authors use the following methods:

a. Inductive method, is a method of writing based on existing theories. About the symptoms observed from things that are specific to things that are general.

b. Deductive method is a method of writing or processing data that comes from special knowledge.

c. Comparative method, is comparing two or more about a thing, then choosing the one that is considered most appropriate.

d. Data were analyzed using descriptive statistical analysis, in the form of a percentage with the following formula:

$$
\begin{aligned}
& \qquad \frac{\mathrm{F}}{\mathrm{N}}=100 \% \\
& \mathrm{P}=\text { Percentage rate } \\
& \mathrm{N}=\text { Frequency that is being sought percentage } \\
& \mathrm{F}=\text { Number of frequencies } / \text { number of individuals }
\end{aligned}
$$

\section{Result and Discussion}

A. The ability to read and write the Qur'an students in SDN Inpres 12/79 Kampuno Barebbo Subdistrict Bone Regency

The Qur'an fosters and educates people, then cleans their souls, removes their filth, educates their minds, shows their talents, sharpens their spirits, elevates their ideals, hones their talents, strengthens their will, strengthens their virtues in their souls, instills faith in their hearts, fulfills their spirit his heart with affection, pushed his hands to do something useful (Al-Hamid, 2002). In this case, the ability to read and write the Qur'an in SDN Inpres 12/79 Kampuno gives an important meaning in improving student achievement in Islamic education. Al-Qur'an is a miracle and the first source of Islamic law, this is honestly very recognized by Baba, S.Pd, headmaster of SDN Inpres 12/79 Kampuno that:

"The ability to read and write the Qur'an greatly influences the learning achievement of Islamic education, because Al Qur'an is a miracle, the Qur'an is a source of law, and Islamic education material is related to the Qur'an and Hadith so that students who are unable to read the Qur'an will not possibly have satisfactory achievements in learning Islamic education".

To find out the level of reading and writing ability of the Qur'an, SDN Inpres 12/79 Kampuno students pay attention to the following table:

Table 1. Level of respondents' ability in reading and writing Al Qur'an

\begin{tabular}{clcc}
\hline No. & Ability level & Frequency & Percentage \\
\hline 1. & Fluent & 20 & $66,6 \%$ \\
2. & Ablet, but not yet fluent & 9 & $30 \%$ \\
3. & Has not been able to & 1 & $3,4 \%$ \\
\hline & Total & 30 & $100 \%$
\end{tabular}

Data source: The results of questionnaire processing number 1 and direct test to read and write $\mathrm{Al}$ Qur'an

B. Factors influencing the ability to read and write Al-Qur'an on the students of SDN Inpres 12/79 Kampuno Barebbo Sub-district Bone Regency

Modern world has brought humanity to the era of progress but on the other hand has changed the fabric of society including the morale of young people and children. Negative influence is seen in their moral decay that occurred not only in the Western world, but began to spread to the Islamic world, including Indonesia. Damage varies from mild to classify as severe damage, such as fighting, killing and robbery. These conditions require serious coaching for the younger generation, especially early childhood. 
One alternative to moral development is to teach them to read and write the Qur'an, because the Qur'an is the only way of life to achieve salvation, peace and success in wading through life full of challenges.

In the teaching and learning process, there are several things that affect one's ability as well as reading and writing the Qur'an. There are two factors: internal and external factors as stated by Nurhidaya, S.Pd.I a, Islamic Education Teacher at SDN Inpres 12/79 Kampuno:

"There are two factors that affect the ability to read and write Al-Qur'an students in SDN Inpres 12/79 Kampuno, internal factors, namely the willingness of students to study the Qur'an then external factors include the family environment, school environment and society".

Internal factor is the willingness of students to improve their literacy skills. Students who have a great will always try to improve their literacy skills by always actively following the guidance in school. While external factors, namely environmental factors, in this case include the family environment and school environment. Both of these environments are very influential on improving the literacy skills of the students at SDN Inpres 12/79 Kampuno, Barebbo District, Bone Regency, where the family environment functions as a teacher as well as educators is parent or trustee. This was stated by one of the teachers of SDN Inpres 12/79 Kampuno:

"Parents of students have a big role in improving the ability to read and write the Qur'an in SDN Inpres 12/79 Kampuno".

School environment also has a large role in improving the reading and writing of the Qur'an as revealed by one of the students of SDN Inpres 12/79 Kampuno:

"Schools have a great influence on improving the reading and writing of the Qur'an, because before I entered this school (SDN Inpres 12/79 Kampuno), reading and writing of the Qur'an I was very bad and and now Alhamdulillah reading and writing my Qur'an is quite satisfying, because the school provides special guidance on reading and writing the Qur'an outside of school hours, 3 times a week which is Saturday, Monday and Wednesday, 1.30-2.30 pm".

Community environment also has an influence on improving literacy in students of SDN Inpres 12/79 Kampuno. Based on interviews with Islamic Education Teacher of SDN Inpres 12/79 Kampuno.

"Community's environment also has an influence on improving the reading and writing of $\mathrm{Al}$ Qur'an students in SDN Inpres 12/79 Kampuno, because the community is where they interact in their daily lives".

Based on these factors, to further enhance the ability to read and write the Qur'an, collaboration is needed between students, schools and the community

C. Influence of the ability to read and write the Qur'an to the learning achievement of Islamic education for students in SDN Inpres 12/79 Kampuno

Influence of the ability to read and write the Koran on the academic achievement of Islamic education for students can be seen in table 2 .

Table 2. The influence of the ability to read and write Al-Qur'an on learning achievement of Islamic Education

\begin{tabular}{clcc}
\hline No. & Answer Category & Frequency & Percentage \\
\hline 1. & Very influential & 30 & $100 \%$ \\
2. & Less influential & - & - \\
3. & No influential & - & - \\
4. & Quite influential & - & - \\
\hline & Jumlah & 30 & $100 \%$ \\
\hline
\end{tabular}

Data Source: Questionnaire process number 3

Table shows that out of 30 students or 100\% respondents stated that the ability to read and write Al-Qur'an on students greatly affects the learning achievement of Islamic education. From this description it can be seen that students who have a good reading and writing of the $\mathrm{Al}$ Qur'an have a 
good achievement score in studying Islamic education in SDN Inpres 12/79 Kampuno, thus the ability to read and write the Qur'an for participants students have an influence on learning achievement of Islamic education.

\section{Conclusion}

Ability to read and write the Qur'an for students in SDN 12/79 Kampuno, Barebbo Sub-district, Bone Regency is fluent but still needs intensive guidance in the future. In the teaching and learning process there are several things that affect the learning achievement of students in SD Inpres 12/79 Kampuno, namely internal factors which include physiological conditions, namely general physiological and sensory, psychological conditions, namely interest, intelligence, talent, motivation and cognitive abilities. External factors, including family environment factors, school environment and community environment. Ability to read and write Al-Qur'an greatly influences the learning achievement of Islamic education for students in SDN students in SDN 12/79 Kampuno, Barebbo Sub-district, Bone Regency.

\section{References}

Afif AFT. 1988. Rubul dinul Islam, XXVII ed. Beirut Libanon: Darul Ilmi Malayin.

Ahmad HM et al. 1415 H. Qur'an Hadits Madrasah Aliyah Kelas I, 1st ed. Bandung: Armico.

Al-Hamshy HAR. 2003. al-Athfaal Babjat al-Hayaah wa Amal al-Mustqbal, translated by Imran Rosadi. Kiat Mendidik. Anak. Masa Depan, 1st ed. Jakarta: Najla Press.

Ali HM. 2002. Guru dalam Proses Belajar Mengajar, XI ed. Bandung: Sinar Baru Algesindo.

Al-Khattan MK. 1412 H. Mabahis fi Ulumil Qur'an, III ed. Riyad: Mansyurat al-Asr al-Hadis.

As-Suyuthi JAI. 1996. Asraru Tartibil Qur'an, translated by Masdar Helmi. Rabasia Susunan Surab Al-Qur'an menurut Tertib Mushbab, 1st ed. Jakarta: Pustaka Amani.

Ath-Thuwairaqi N and Al-Idaarah TFA. 2004. Sekolah Unggulan berbasis Sirah Nabawiyah, 1st ed. Jakarta: Darul Falah.

Basalamah HSM. 1997. Pengantar Ilmu Al-Qur'an, 1st ed. Semarang: PT. Karya Toha Putra.

Departemen Agama RI. 1971. Al-Qur'an \& Terjemahnya. Jakarta: Yayasan Penyelenggara Penterjemah / Pentafsir Al-Qur'an.

Departemen Pendidikan Nasional. 2003. Kamus Besar Bahasa Indonesia. Jakarta: Balai Pustaka.

Fauzi AH. 1999. Psikologi Umum, 2nd ed. Bandung: CV. Pustaka Setia.

Hasbullah. 2005. Dasar-Dasar Pendidikean, 4th ed. Jakarta: PT. Raja Grafindo.

Imam N. 2001. Al-Tibyam fi adab hamalat Al-Qur'an, translated by Tramana Ahmad Qasim. Adab Mengajarkan Al-Qur'an, 1 st ed. Jakarta: Hikmah.

Irwan R. 2005. Al-Qur'an Bertutur tentang Makanan dan Obat-Obatan, 1st ed. Yokyakarta: Mitra Pustaka.

Mahfudzh, SMJ. 2004. Attarbiyah al-Islamiyah Littipli Walmarahiq translated by Abdul Rosyad Shiddiq \& Ahmad Yathir Zanan H. Abduh Zulfidar Akaha. Psikologi Anak dan Remaja Muslim, 3rd ed. Jakarta: Pustaka Al-Kautsar.

Qattan M. 1412 H. Mababis fi Ulumil Qur'an, 3rd ed. Riat: Mansyurat Al-Hadits.

Racendra. Kartawiria. 2004. 12 Langkah Membentuk Manusia Cerdas, 1st ed. Jakarta: Hikmah.

Sensa DM. 2005. Quranic Quotient Kecerdasan-Kecerdasan Bentukan Qur'an, 3rd ed. Jakarta: Hikmah.

Shihab MQ. 1997. Wawasan Al-Qur'an, 4th ed. Bandung: Mizan.

Sudjana N. 2004. Dasar-Dasar Proses Belajar Mengajar, VII ed. Bandung: Sinar Baru Al-Gesindo.

Suwaid AH and Nur M. 1422 H. Manhaj At-Tarbiyah an-nabawiyah Littifli, Dar Al-Wafa Al-Mansurah, 3rd ed. Makkatul Mukarramah: Daru Tibatul Hadrah. 